\section{СІЛЬСЬКІ ТЕРИТОРІЇ: СУТНІСТЬ КАТЕГОРІЇ ТА ІНДИКАТОРИ ÏÏ ОЦІНКИ ${ }^{15}$}

\author{
КОСТЮЧЕНКО Д.Л., \\ аспірантка, \\ асистент кафедри економіки, \\ Вінницький національний \\ аграрний університет \\ (м. Вінниця)
}

У статті розглянуто науково-теоретичні підходи науковців до визначення дефініції «сільські території». Зазначено, щцо від формулювання залежатиме оцінка сільських територій як платформи для економічного, соціального, екологічного, тощяо розвитку, методичних підходів до діагностики ї̈ стану та вибір технологій управління для формування ефективного механізму розвитку сільських територій. Проаналізовано нормативно-правову базу щодо трактування поняття «сільська територія», та зроблено припущення, щуодо максимальної чисельності населення села. На основі опрацьованих джерел сформульовано авторське визначення категорії «сільські території», як складної, динамічної, відкритої сочіо-еколого-економічної системи.

У результаті розглянутих складових комплексного аналізу стану сільських територій, алгоритму вивчення сільських територій та основних показників, щяо характеризують рівень розвитку сочіальної інфраструктури, виокремлено основні блоки комплексної оцінки сільських територій, до яких належать: оцінка економічного розвитку, оцінка соціального розвитку, оцінка стану довкілля, оцінка демографічного стану та аналіз фінансового забезпечення. Опрацьовано показники, індекси та критерії, за якими науковці оцінюють рівень розвитку сільської території.

Установлено, щзо при формуванні індексу розвитку сільських територій має бути наявний показник ВВП, однак, головну роль має відігравати набір показників, щуо пов'язані саме з людиною та навколишнім середовищем.

Автором запропоновано показники, які мають входити до інтегрального показника розвитку сільських територій, які групуються за чотирма складовими: економічною, екологічною, соціальною та демографічною. Зроблено припущення, щзо такий підхід забезпечить усебічний аналіз та оцінку явищ та процесів, щуо відбуваються у сільських територіях; дозволить виявити аттрактори їхнього розвитку; виявить напрями, які можуть бути кориговані та змінять мейстрими розвитку сільських територій.

Ключові слова: сільські території, інтегральний індикатор, оцінка стану розвитку сільських територій, індекс розвитку сільських територій, аналіз стану сільських територій, показники розвитку.

Табл.: 2. Рис.: 1. Літ.: 16.

\title{
RURAL AREAS: THE ESSENCE OF THE CATEGORY AND INDICATORS OF ITS EVALUATION
}

${ }^{15}$ КОСТЮЧЕНКО Д.Л., 2020 


\title{
KOSTIUCHENKO Daryna, Post-graduate Student, Lecturer of the Department of Economics, Vinnytsia National Agrarian University
}

(Vinnytsia)

The article deals with the scientific-theoretical approaches of scientists to the definition of "rural territories". It is stated that the formulation will depend on the assessment of rural areas as a platform for economic, social, environmental, etc. development, methodological approaches to the diagnosis of its condition and the choice of management technologies to form an effective mechanism for rural development. The legal base on the interpretation of the concept of "rural territory" is analyzed and the assumption is made regarding the maximum population of the village. Based on the elaborated sources, the author defines the author's definition of the category "rural territories" as a complex, dynamic, open socio-ecological-economic system.

As a result of the considered components of the complex analysis of the state of rural territories, the algorithm of study of rural territories and the main indicators characterizing the level of development of social infrastructure, the main blocks of integrated assessment of rural territories are identified. status and analysis of financial security. Indicators, indices and criteria by which scientists evaluate the level of rural development are analyzed. It has been established that a GDP index should be present in the development of a rural development index, but a set of indicators related to the individual and the environment should play a major role.

The author proposes indicators that should be included in the integrated indicator of rural development, which are grouped into four components: economic, environmental, social and demographic. It is assumed that this approach will provide a comprehensive analysis and evaluation of the phenomena and processes occurring in rural areas; will identify attractors of their development; identify areas that can be corrected and change the rural development masters.

Keywords: rural territories, integral indicator, assessment of rural development, rural development index, analysis of rural areas, development indicators.

Tabl.: 2. Fig.: 1. Lit.: 16.

\section{СЕЛЬСКИЕ ТЕРРИТОРИИ: СУЩНОСТЬ КАТЕГОРИИ И ИНДИКАТОРЫ ЕЕ ОЦЕНКИ}

\author{
КОСТЮЧЕНКО Д. Л., \\ аспирантка, ассистент кафедры экономики, \\ Винницикй национальный аграрный университет \\ (2. Винница)
}

В статье рассмотрены научно-теоретические подходы ученых $\kappa$ определению дефиниции «сельские территории». Отмечено, что от формулировки будет зависеть оценка сельских территорий как платформы для экономического, социального, экологического и т.д. развития, методических подходов $\kappa$ диагностике ее состояния и выбор технологий управления для формирования эффективного механизма развития сельских территорий. Проанализировано нормативно-правовую базу относительно трактовки понятия «сельская территория», и сделано предположение, по максимальной численности населения села. На основе обработанных источников сформулировано авторское определение категории «сельские территории», как сложной, динамичной, открытой сочио-эколого-экономической системы. 
В результате рассмотренных составляющих комплексного анализа состояния сельских территорий, алгоритма изучения сельских территорий и основных показателей, характеризующих уровень развития социальной инфраструктуры выделень основнье блоки комплексной оценки сельских территорий, к которым относятся: оценка экономического развития, оченка сочиального развития, оченка состояния окружающей среды, оченка демографического состояния и анализ финансового обеспечения. Обработано показатели, индексы и критерии по которым ученые оценивают уровень развития сельской территории. Установлено, что при формировании индекса развития сельских территорий должен присутствовать показатель ВВП, однако главную роль должен играть набор показателей, связанных именно с человеком и окружающим его средой.

Автором предложены показатели, которые должны входить в интегральныий показатель развития сельских территорий, которые группируются по четырем составляюшим: экономической, экологической, социальной и демографической. Сделано предположение, что данный подход обеспечит всесторонний анализ и оценку явлений $u$ прочессов, происходящих в сельских территориях; позволит обнаружить аттракторы их развития; обнаружит направления, которые могут быть корректируемые и изменят мейстримы развития сельских территорий.

Ключевые слова: сельские территории, интегральный индикатор, оценка состояния развития сельских территорий, индекс развития сельских территорий, анализ сельских территорий, показатели развития.

Табл.: 2. Рис.: 1. Лит.: 16.

Постановка проблеми. Роль сільських територій у соціальноекономічному житті країни з кожним днем підвищується. Важливість територій для економіки країни посилюється їхнім особливим внеском у формування основ продовольчої безпеки. Цей та інші чинники роблять розвиток сільських територій одним з головних пріоритетів державної політики України, націленої на зростання рівня життя сільського населення, підвищення ефективності функціонування АПК, покращення стану довкілля та поліпшення якості людського капіталу. Незважаючи на увагу, яка останнім часом приділяється сільським територіям 3 боку науковців, поки що залишається дискусійним питання про ідентифікацію відповідної категорії. Адже від іiі формулювання залежатиме оцінка сільських територій як платформи для економічного, соціального, екологічного тощо розвитку, методичних підходів до діагностики їі стану та вибір технологій управління для формування ефективного механізму розвитку сільських територій.

Згідно зі статистичними даними FAO (Продовольча та сільськогосподарська організація об'єднаних націй) на сільські території у світі у 2008 - 2018 роках приходилось більше 80 \% території, на яких проживало більше 40 \% населення.

Статистичні дані свідчать про ключове значення сільських територій для розвитку світових економічної та соціальної системи. При цьому, відзначимо поступове зниження як площі територій (-2,4 \% за період з 2008p. по 2018p.), так і кількості населення (-4,8 \% за період з 2008р. по 2018p.), які належать до сільської місцевості. Така ситуація була викликана з одного боку активним 
розвитком міст, а 3 іншого - значними диспаритетами у розвитку міст та сільських територій.

Аналіз останніх досліджень і публікацій. Дослідженням сутності категорії «сільські території», особливостям їхнього функціонування, розвитку та управління присвячена певна кількість публікацій вітчизняних і зарубіжних вчених. До українських вчених, які сформували поняття сільських територій належать: I. Гончаренко [3], А. Сава [13], А. Мазур, I. Гончарук [4], I. Томашук [4], Х. Притула [11], М. Лесів [9]. Серед зарубіжних вчених, які присвятили свої публікації сільським територіям, варто назвати К. Джонсона, Е. Ларсона, Г. Харта, О. Конечного.

Оцінювання стану розвитку сільських територій опрацювали у своїх працях: В. Залізко [6], Т. Свсюков [5], І. Ковальчук [5], А. Сава [12], Х. Притула [11], Н. Шпік [15]. На тлі всебічного розгляду проблеми сільської території визначення ii сутності та специфіки, питання, пов’язані 3 формулюванням адекватного сучасним умовам розвитку індикативного інструментарію досліджені недостатньо.

Формулювання цілей статті. Метою статті $\epsilon$ дослідження сутності поняття «сільські території» та визначення авторського підходу до основних індикаторів оцінки стану їі розвитку.

Виклад основного матеріалу. У трансформаційний період розвитку: суспільства, коли старі структури вже не діють, а нові тільки створюються, система представницької та виконавчої влади повинна забезпечити економічний і соціальний порядок, здійснити політичні, соціальні та економічні реформи, зокрема у питаннях економічного розвитку сільських територій [4]. Тому категорія «сільська територія» змінюється відповідно до цих впливів, набуваючи більш глибокого і визначального змісту. У таблиці 1 наведемо найпоширеніші підходи вчених до категорії «сільські території».

У законопроєкті України № 8051 «ро засади та порядок вирішення питань адміністративно-територіального устрою України» від 22.02.2018 р. зазначено, що «до категорії села належить населений пункт 3 садибною забудовою, невеликим за кількістю населенням, сформований в умовах переважної зайнятості його жителів у сільському, лісовому чи рибному господарстві, народних промислах, первинній переробці сільськогосподарської, лісової чи рибної продукції». «До категорії селищ належить населений пункт з переважно садибною забудовою, соціальною i комунальною інфраструктурою, який пов'язаний $з$ розташуванням на його території промислового підприємства, підприємства з виробництва і переробки сільськогосподарської, лісової, рибної продукції, залізничного вузла, гідротехнічної чи іншої споруди і має населення 워 понад 500 осіб» [7]. Цим законопроєктом визначено, що «до категорії міста належить населений пункт, на території якого розміщені промислові і переробні Іаे підприємства, підприємства комунального господарства, житловий фонд, мережа соціально-культурних закладів і підприємств, який має розвинену соціальну і комунальну інфраструктуру, мережу вулиць з переважно твердим 
покриттям, чисельністю населення не менше 5 тисяч осіб», 3 чого робимо припущення, що максимальна чисельність населення села обмежується цією кількістю жителів [7].

Таблиия 1

\section{Теоретичні підходи науковців до визначення категорії «сільські}

\section{території»}

\begin{tabular}{|c|c|}
\hline I. Гончаренко & $\begin{array}{l}\text { сільська територія - це складна і багатофункціональна природна, соціально-економічна } \\
\text { і виробничо-господарська структура, що характеризується сукупністю властивих ій } \\
\text { особливостей, а саме: площею земельних угідь; особливостями ландшафту; } \\
\text { чисельністю проживаючих людей і типом іх зайнятості; чисельністю, видовим } \\
\text { різноманіттям рослинного і тваринного світу; обсягами і структурою виробництва; } \\
\text { розвитком соціальної і виробничої інфраструктури та іншими рисами }\end{array}$ \\
\hline Ф. Мантіно & $\begin{array}{l}\text { сільські території або сільський регіон (район) охоплює людей, територію та інші } \\
\text { ресурси суспільного ландшафту і маленьких населених пунктів за межами } \\
\text { безпосередньої сфери економічної активності великих міських центрів. А критерієм } \\
\text { віднесення поселення до міста чи села є густина населення понад } 150 \text { людей на } 1 \text { км }\end{array}$ \\
\hline М. Лесів & $\begin{array}{l}\text { сільські території-це сформована на основі найдавнішої форми просторової організації } \\
\text { людських поселень соціально-культурна система еколого-географічних та економіко- } \\
\text { суспільних утворень у природно-культурному середовищі їхнього розташування, яка } \\
\text { знаходиться за межами міст і міських агломерацій. Визначальною ознакою, що } \\
\text { відрізняє село від міста, відзначає автор, є наближеність до природи, яку в процесі } \\
\text { еволюції людина частково адаптувала до власних потреб, однак не перетворила ії в } \\
\text { місто }\end{array}$ \\
\hline А. Сава & $\begin{array}{l}\text { сільська територія - це складна, динамічна, комплексна природно- } \\
\text { ресурсна, адміністративно-територіальна, соціально-демографічна, економіко-галузева } \\
\text { система із наявною на ній сукупності ресурсів, населення, виробничих структур }\end{array}$ \\
\hline
\end{tabular}

Ю. Когатько визначає обернену закономірність між рівнем бідності та розміром населеного пункту: основна проблема полягає в бідності не тільки виключно сільського населення, а в гіршому матеріальному становищі домогосподарств малих населених пунктів, проте селу більше властива немонетарна складова бідності [8]. Чернятіна В. підтримує його думку, стверджуючи, що проживання родини в сільській місцевості підвищує ризик немонетарної бідності у 2,5 разу [14]. У «EU Agricultural Economic briefs. Poverty in rural areas of the EU» зазначено, що ризик бідності $\epsilon$ найвищим в малонаселених пунктах. Близько третини усіх людей, схильних до цього ризику, живе в малонаселених сільських районах [16].

Проаналізувавши наявні визначення поняття «сільські території», вважаємо за доцільне дати авторське визначення цієї категорії: сільська територія складна, динамічна, відкрита соціо-еколого-економічна система, що характеризується низькою, порівняно з містом, щільністю населення на одиницю площі, яке проживає в екологічно-сприятливих умовах мінімально насичених викидами промислового виробництва та задіяне переважно в одноосібному фермерському господарстві.

Х. Притула візначає, що у практиці Євростату моніторинг розвитку сільських територій концентрується на даних про якість ведення сільського 
господарства. У міжнародній практиці термін «sustainable agriculture» означає тривале, стабільне ведення сільськогосподарської діяльності без надмірного виснаження природних ресурсів й без завдання серйозної шкоди навколишньому середовищу. Такий підхід уже досить активно використовується для оцінки розвитку невеликих фермерських господарств, для яких сільське господарство $€$ основною діяльністю та способом життя [11].

T. Свсюков та I. Ковальчук [5] стверджують, що комплексний аналіз сучасного стану сільських територій грунтується на складниках, які автор пропонує розглядати в розрізі блоків проблем:

1) соціальних (дослідження соціальних негараздів (проблем) села;

2) економічних (аналіз наявної матеріально-технічної і фінансової бази розвитку села, пошуки засобів їхньої оптимізації та розв'язування наявних проблем, дослідження виробничої, управлінської та побутової інфраструктури села, аналіз ефективності ведення сільського господарства);

3) природо-ресурсних (оцінювання геодемографічного і працересурсного потенціалу сільської місцевості, виявлення проблемних питань, пошуки шляхів їх розв'язання, аналіз структури землекористувань, iї динаміки, загроз і ризиків, § повязаних 3 реформуванням земельних відносин, аналіз та оцінювання природно-ресурсного потенціалу розвитку села. аналіз якості грунтів, їхньої потенційної врожайності, агроекологічного стану, деградаційних процесів, багаторічних змін цих параметрів, аналіз лісогосподарських проблем, визначення їхньої гостроти і послідовності вирішення, дослідження об'єктів водного фонду і водного господарства, аналіз водогосподарських проблем);

4) організаційно-правових (аналіз проблем, пов'язаних з недосконалістю організаційно-правових засад розвитку села і сільського господарства);

5) екологічних (аналіз та оцінювання гостроти екологічних, медикогеографічних, природоохоронних, рекреаційних проблем сільської місцевості, 今 аналіз та оцінювання екологічної ефективності землекористування згідно з міжнародним стандартом ISO 14031).

А. Сава пропонує загальний алгоритм оцінки сільських територій, який характеризується декількома взаємопов'язаними процедурами:

1) обгрунтування критеріїв дослідження, визначення основних чинників і показників розвитку сільських територій, оцінку їх значущості;

2) оцінка розвитку сільських територій за основними підсистеми (економічної, соціальної, екологічної);

3) обчислення інтегрального показника розвитку сільських територій та порівняння його із нормативними значеннями;

4) оцінка загальної асиметричності соціально-економічного розвитку сільських територій в межах регіонів та країни загалом;

5) визначення критеріальних меж рівнів розвитку сільських територій;

6) типізація сільських територій за рівнем їх розвитку;

7) розроблення принципів і загальних підходів до формування системи заходів стимулювання розвитку сільських територій; 
8) прогнозування показників розвитку сільських територій на національному рівні;

9) розроблення цільових програм соціально-економічного розвитку сільських територій в окремих регіонах країни [13].

Оскільки соціальна складова $є$ пріоритетною для розвитку будь-якої території пропонується розглядати показники, що характеризують рівень розвитку соціальної інфраструктури сільських територій, на думку Н. Шпіка та О. Микули [15]:

- вартісні (оцінка основних фондів та експлуатаційних витрат, обсяг послуг і роздрібного товарообігу);

- натуральні (рівень забезпечення житлом сільського населення, торговельна й інша площа будинків, обладнання житлових площ комунікаціями, стан доріг тощо);

- трудові (кількість зайнятого населення, загальний демографічний стан, рівень професійної підготовки, демографічне навантаження на працездатне населення, вікова структура сільського населення);

- якісні (технічний стан об'єктів соціально-культурного побуту, інженерне устаткування сільського житлового фонду) [15].

На основі вищенаведеного автором пропонується здійснювати комплексну оцінку розвитку сільських територій за блоками (рис. 1).

Оцінка економічного розвитку. Показники: коефіцієнт територіальної різноманітності природно-ресурсного потенціалу, частка виробленої валової продукції, яка припадає на одного мешканця району, інвестиції в основний капітал на одну особу, частка малих підприємств у виробництві продукції району, коефіцієнт Енгеля.

Оцінка соціального розвитку. Показники: частка зайнятих у сільському господарстві, рівень зареєстрованого безробіття, середньомісячна заробітна плата, товарообіг на одну особу, обсяг реалізованих послуг на одну особу.

Оцінка стану довкілля. Показники: викиди шкідливих речовин та парникових газів в атмосферне повітря, утворення небезпечних відходів за класами небезпеки.

Оцінка демографічного стану. Показники: природний приріст населення (в тому числі порівняно 3 природним приростом усього населення), динаміка чисельності населення, сальдо міграцій сільського населення, його щільність, людність сільських поселень.

Аналіз фінансового забезпечення. Показники: частка власних доходів у бюджеті та доходи районних бюджетів у розрахунку на одного мешканця району.

Рис. 1. Основні блоки комплексної оцінки сільських територій Джерело: сформовано автором за [1,2]

В. Залізко вважає, що у формуванні індексу розвитку сільських територій має бути присутній показник ВВП (за аналогією з ІЛР), проте головну роль має 
відігравати набір показників, що пов'язані саме 3 людиною та навколишнім середовищем - природою. Нова система показників має стимулювати економіку сільських територій до остаточного еволюційного переходу від прагматичного „доходоцентризму“ (до недавнього часу основним був екстенсивний шлях розвитку: більше розорати, посіяти, зібрати, продати і т.д.) до демократичного „селяноцентризму“, що був розвинений із загально-світової гуманістичної теорії „людиноцентризму“, згідно з якою людина є головним об’єктом будь-якого розвитку [6]. Він пропонує набір соціально-економічних показників, що впливатимуть на індекс розвитку сільських територій, виходячи 3 аналізу можливості їх статистичної обробки та задоволення наступної ієрархії принципів:

- селяноцентризм (основним є розвиток місцевих жителів - селян);

- природоцентризм (головним є збереження та відтворення довкілля природи, яка, в основному, зосереджена в межах сільських територій);

- доходоцентризм (основним є збільшення доходів та матеріальних благ).

Ми пропонуємо включити до принципів розвитку сільських територій та індикаторів їхнього розвитку в групу, яка зосереджена на соціальних показниках.

На нашу думку, інтегральний показник розвитку сільських територій має включати складові, які наведені в таблиці 2.

Складові та показники інтегрального показника розвитку сільських територій

\begin{tabular}{|l|l|}
\hline Складова & \multicolumn{1}{|c|}{ Показники } \\
\hline Економічна & $\begin{array}{l}\text { Коефіцієнт територіальної різноманітності природно-ресурсного потенціалу, частка } \\
\text { виробленої валової продукції, яка припадає на одного мешканця району, інвестиції в } \\
\text { основний капітал на одну особу, частка малих підприємств у виробництві продукції району, } \\
\text { коефіцієнт Енгеля. }\end{array}$ \\
\hline Екологічна & $\begin{array}{l}\text { Викиди шкідливих речовин та парникових газів в атмосферне повітря, утворення } \\
\text { небезпечних відходів за класами небезпеки. }\end{array}$ \\
\hline Соціальна & $\begin{array}{l}\text { Кількість зайнятого населення, частка зайнятих у сільському господарстві, рівень } \\
\text { зареєстрованого безробіття, середньомісячна заробітна плата, товарообіг на одну особу, } \\
\text { обсяг реалізованих послуг на одну особу, оцінка основних фондів та експлуатаційних витрат, } \\
\text { обсяг послуг і роздрібного товарообігу, рівень забезпечення житлом сільського населення, } \\
\text { торговельна й інша площа будинків, обладнання житлових площ комунікаціями, стан доріг, } \\
\text { технічний стан об'єктів соціально-культурного побуту, інженерне устаткування сільського } \\
\text { житлового фонду, ризик бідності населення. }\end{array}$ \\
\hline Демографічна & $\begin{array}{l}\text { Природний приріст населення (в тому числі порівняно з природним приростом усього } \\
\text { населення), динаміка чисельності населення, сальдо міграцій сільського населення, щіль- } \\
\text { ність населення, людність сільських поселень, загальний демографічний стан, рівень } \\
\text { професійної підготовки, демографічне навантаження на працездатне населення, вікова } \\
\text { структура сільського населення, }\end{array}$ \\
\hline
\end{tabular}

Джерело: сформовано автором

Інтегральний показник розвитку сільських територій має включати в себе економічну, екологічну, соціальну та демографічну складові.

Висновки. Отже, автором визначено сутність категорії «сільська територія». Це - складна, динамічна, відкрита соціо-еколого-економічна 
система, що характеризується низькою, порівняно з містом, щільністю населення на одиницю площі, яке проживає в екологічно-сприятливих умовах мінімально насичених викидами промислового виробництва та задіяне переважно в одноосібному фермерському господарстві. У процесі дослідження встановлено, що складна система, якою є сільська територія, передбачає адекватні структурі методологічні підходи, які базуються на комплексній оцінці сукупності показників.

Такий підхід, по-перше, забезпечить усебічний аналіз та оцінку явищ та процесів, що відбуваються у сільських територіях та $є$ для них характерними; подруге, дозволить виявити аттрактори їхнього розвитку, на яких варто сконцентрувати увагу при формуванні системи управління сільськими територіями; по-третє, виявити напрями, які можуть бути кориговані та змінять мейстрими розвитку сільських територій; по-четверте, забезпечить вибір індикаторів оцінки сільських територій, які володіють адаптивно- коригувальними властивостями та здатні забезпечити реальну оцінку сільської території у тривалому часовому проміжку. Зазначені положення потребують подальших наукових досліджень та будуть більш широко розкриті у наступних публікаціях.

\section{Список використаних джерел}

1. Балдинюк В. М. Методичні підходи до оцінки комплексного розвитку сільських територій. Державне управління: удосконалення та розвиток. 2011. № 9. URL: http://nbuv.gov.ua/UJRN/Duur_2011_9_14 (дата звернення 10.05.2019)

2. Барановський М. О. Наукові засади суспільно-географіного вивчення сільських депресивних територій України: монографія. Ніжин : ПП Лисенко М. М., 2009. 396 с.

3. Гончаренко I. В. Соціально-економічний розвиток сільських територій регіону: проблеми теорії та практики: монографія. Львів: Інститут регіональних досліджень НАН України, 2009. 370 с.

4. Гончарук I.В., Томашук I.В. Вплив еколого-економічного фактору на особливості організаційно-економічного механізму використання ресурсного потенціалу сільських територій. Економіка. Фінанси. Менеджмент: актуальні питання науки і практики. 2017. №4. С.52-62.

5. Євсюков Т.О., Ковальчук І.П. Дослідження сучасного стану сільських територій: підходи, алгоритми, методи. 2011. URL: https://zsu.org.ua/tarasevsyukov/125-2011-04-07-13-57-41 (дата звернення 20.05.2019)

6. Залізко В.Д. Формування системи соціально-економічних показників розвитку регіонів України на прикладі сільських територій. Науковий вісник НГУ. 2014. № 2. С. 119-126.

7. Про засади та порядок вирішення питань адміністративнотериторіального устрою України: Законопроект України від 22.02.2018 № 8051 URL:http://www.minregion.gov.ua/wp-content/uploads/2016/03/Pr-ZU-proATU.pdf (дата звернення 10.05.2019). 
8. Когатько Ю.Л. Бідність сільського населення України. Демографія та соиіальна економіка. 2015. № 1 (23). С. 32-43.

9. Лесів М. М. Організаційно-економічні механізми забезпечення розвитку сільських територій країн-членів європейського союзу: дис. на здобуття наукового ступеня к.е.н. 08.00.02/ Львів, 2015. 224 с.

10. Мантино Ф. Сельское развитие в Европе. Политика, институты и действующие лица на местах с 1970-х годов до наших дней. URL: http://www.eastagri.org/publications/pub_docs/ Mantino.pdf

11. Притула X. М. Соціально-економічний розвиток сільських територій: регіональний вимір: монографія. Львів: Ін-т регіон. дослідж. ім. М. І. Долішнього, 2015. 354 с.

12. Сава А.П. Обгрунтування методологічних підходів до вивчення розвитку сільських територій. Сталий розвиток економіки. 2017. №2. С. 33-40.

13. Сава А.П Обгрунтування процедурних особливостей методології оцінки розвитку сільських територій. Подільський вісник: сільське господарство, техніка, економіка. 2017. №26 (2). С. 204-215.

14. Чернятіна В. А. Державне регулювання сталого розвитку сільських територій в Україні. Державне управління та місиеве самоврядування. 2017. №3(34). С. 122-127.

15. Шпік Н., Микула О. Основні показники розвитку соціальної інфраструктури сільських територій. Вісник Львівського національного аграрного університету. Сер : Економіка АПК. 2013. № 20(2). С. 34-37.

16. Poverty in rural areas of the EU: Brief №1. May 2011. URL: http://ec.europa.eu/agriculture/rural-area-economics/briefs/pdf/01_en.pdf.

\section{References}

1. Baldyniuk, V. M. (2011) Metodychni pidkhody do otsinky kompleksnoho rozvytku silskykh terytorii. [Methodological approaches to the assessment of integrated rural development]. Derzhavne upravlinnia: udoskonalennia ta rozvytok 2011 - Public administration: improvement and development, № 9. Retrieved from http://nbuv.gov.ua/UJRN/Duur_2011_9_14 f [in Ukrainian].

2. Baranovskyi, M. O. (2009) Naukovi zasady suspilno-heohrafinoho vyvchennia silskykh depresyvnykh terytorii Ukrainy: monohrafiia [Scientific principles of socio-geographical study of rural depressed territories of Ukraine: monograph]. Nizhyn: PP Lysenko M. M., 396.

3. Goncharenko, I.V. (2009) Social and economic development of rural areas of the region: problems of theory and practice: monograph [Socio-economic development of rural areas of the region: problems of theory and practice: monograph]. Lviv: Institute for Regional Studies of the National Academy of Sciences of Ukraine, 370.

4. Goncharuk I.V., Tomashuk I.V. (2017) Vplyv ekologo-ekonomichnogo faktoru na osoblyvosti organizacijno-ekonomichnogo mexanizmu vykorystannya resursnogo potencialu silskyx terytorij. [Influence of ecological-economic factors on the peculiarities of the organizational-economic mechanism of use of resource potential 


\section{ЕФМ}

http://efm.vsau.org/

of rural territories]. Ekonomika. Finansy. Menedzhment: aktualni pytannya nauky $i$ praktyky - Economy. Finances. Management: topical issues of science and practical activity, №4. 52-62

5. Yevsiukov, T.O., \& Kovalchuk I.P. (2011) Doslidzhennia suchasnoho stanu silskykh terytorii: pidkhody, alhorytmy, metody [Research of the present state of rural territories: approaches, algorithms, methods]. Retrieved from https://zsu.org.ua/tarasevsyukov/125-2011-04-07-13-57-41 [in Ukrainian].

6. Zalizko, V.D. (2014) Formuvannia systemy sotsialno-ekonomichnykh pokaznykiv rozvytku rehioniv Ukrainy na prykladi silskykh terytorii [Formation of the system of socio-economic indicators of the development of regions of Ukraine on the example of rural areas]. Naukovyi visnyk NHU - Scientific bulletin of NMU, № 2. 119126.

7. Pro zasady ta poriadok vyrishennia pytan administratyvno-terytorialnoho ustroiu Ukrainy: Zakonoproekt Ukrainy vid 22.02.2018. Retrieved from - URL:http://www.minregion.gov.ua/wp-content/uploads/2016/03/Pr-ZU-pro-ATU.pdf [in Ukrainian].

8. Kohatko, Yu.L. (2015) Bidnist silskoho naselennia Ukrainy [Poverty of the rural population of Ukraine]. Demohrafiia ta sotsialna ekonomika - Demography and Social Economy, № 1 (23). 32-43.

9. Lesiv, M.M. (2015) Orhanizatsiino-ekonomichni mekhanizmy zabezpechennia rozvytku silskykh terytorii krain-chleniv yevropeiskoho soiuzu: dys. na zdobuttia naukovoho stupenia k.e.n. 08.00.02/ Lviv, 224.

10. Mantyno, F. Selskoe razvytye v Evrope. Polytyka, ynstytutb y deistvuiushchye lytsa na mestakh s 1970-kh hodov do nashykh dnei [Rural development in Europe. Politics, institutions and actors in the field from the 1970s to the present.]. Retrieved from http://www.eastagri.org/publications/pub_docs/ Mantino.pdf [in Ukrainian].

11. Prytula, Kh. M. (2015) Sotsialno-ekonomichnyi rozvytok silskykh terytorii: rehionalnyi vymir: monohrafiia [Socio-Economic Development of Rural Areas: Regional Dimension]. Lviv: In-t rehion. doslidzh. im. M. I. Dolishnoho, 354.

12. Sava, A.P. (2017) Obgruntuvannia metodolohichnykh pidkhodiv do vyvchennia rozvytku silskykh terytorii [Justification of methodological approaches to studying the development of rural areas.]. Stalyi rozvytok ekonomiky - Sustainable development of the economy, №2, 33 - 40 [in Ukrainian].

13. Sava, A.P (2017) Obgruntuvannia protsedurnykh osoblyvostei metodolohii otsinky rozvytku silskykh terytorii [Obgruntuvannia protsedurnykh osoblyvostei metodolohii otsinky rozvytku silskykh terytorii.]. Podilskyi visnyk: silske hospodarstvo, tekhnika, ekonomika - Podilskyi visnyk: silske hospodarstvo, tekhnika, ekonomikam, №26 (2), 204 - 215 [in Ukrainian].

14. Cherniatina, V. A. (2017) Derzhavne rehuliuvannia staloho rozvytku silskykh terytorii v Ukraini [State regulation of sustainable development of rural areas in Ukraine]. Derzhavne upravlinnia ta mistseve samovriaduvannia Public administration and local government, №3(34), 122-127 [in Ukrainian]. 
15. Shpik, N., \& Mykula O. (2013) Osnovni pokaznyky rozvytku sotsialnoi infrastruktury silskykh terytorii [The main indicators of the development of social infrastructure of rural areas]. Visnyk Lvivskoho natsionalnoho ahrarnoho universytetu. Ser : Ekonomika APK - Visnyk of Lviv National Agrarian University. Sir: Economy of the agroindustrial complex, № 20(2), 34-37 [in Ukrainian].

16. Poverty in rural areas of the EU: Brief №1 (2011). Retrieved from http://ec.europa.eu/agriculture/rural-area-economics/briefs/pdf/01_en.pdf.

\section{Відомості про автора}

КОСТЮЧЕНКО Дарина Леонідівна - аспірантка, асистент кафедри економіки, Вінницький національний аграрний університет (21008, м. Вінниця, вул. Сонячна, 3, e-mail: Dasha_veres@meta.ua).

KOSTIUCHENKO Daryna - Post-graduate Student, Lecturer of the Department of Economics, Vinnytsia National Agrarian University (21008, 3 Sonyachna st., Vinnytsia, email: Dasha_veres@meta.ua).

КОСТЮЧЕНКО Дарина Леонидовна - аспирантка, асистент кафедры экономики, Винницкий национальный аграрный университет (21008, г. Винница, ул. Солнечная, 3, e-mail: Dasha_veres@meta.ua). 